\title{
MICROORGANISMS IN HYPOGEON: EXAMPLES FROM SLOVENIAN KARST CAVES
}

\section{MIKROORGANIZMI PODZEMLJA: PRIMERI IZ SLOVENSKIH KRAŠKIH JAM}

Janez MULEC

\begin{abstract}
UDC 579.2:551.44

Microorganisms in hypogeon: Examples from Slovenian karst caves

In caves microorganisms inhabit distinct habitats where they develop various interactions. As an evidence of microbial activity several features can be identified. Microorganisms are involved both in lithogenic and litholitic processes. Besides heterotrophs in caves autotrophic organisms can be also expected. Some cyanobacteria and microalgae in caves can survive even at photon flux densities lower than their photosynthetic compensation point. In the paper up-to-date identified groups of microorganisms (bacteria, cyanobacteria, microalgae, fungi and protozoa) with their localities in Slovenian caves are presented. Especially bacteria from caves, as the most diverse group, offer immense biotechnological and bioremediation potential. In caves microbial biomass can be considered a considerable food source for cave-dwelling higher organisms. Caves in Slovenia offer great chances to discover new species, as was fungus $\mathrm{Mu}$ cor troglophilus discovered in association with the cave cricket Troglophilus neglectus.
\end{abstract}

Key words: microorganisms, cave microbiology, karst, Slovenia.
Izvleček UDK 579.2:551.44

Mikroorganizmi podzemlja: primeri iz slovenskih kraških jam

Mikroorganizmi v jamah naseljujejo različne habitate, kjer razvijejo številne interakcije. Kot dokaz mikrobne aktivnosti lahko naletimo na številne biološko pogojene kraške oblike. Mikroorganizmi so vklučeni tako v litogene kot litolitične procese. Poleg heterotrofnih organizmov lahko v jamah pričakujemo tudi avtotrofne. Nekatere cianobakterije in mikroalge lahko preživijo $\mathrm{v}$ jamah tudi pri tistih intenzitetah svetlobe, ki so nižje od njihove fotosintetske kompenzacijske točke. V prispevku so predstavljena nahajališča in mikroorganizmi (bakterije, cianobakterije, mikroalge, glive in praživali), ki so bili do sedaj identificirani v slovenskih jamah. Posebej bakterije, kot najbolj raznovrstna skupina mikroorganizmov, ponujajo ogromen biotehnološki in bioremediacijski potencial. Mikrobna biomasa predstavlja $\mathrm{v}$ jamah upoštevanja vreden vir hrane za višje razvite jamske organizme. Jame v Sloveniji predstavljajo še veliko možnosti za odkritje novih vrst, kot je primer glive Mucor troglophilus, ki je bila odkrita na jamski kobilici Troglophilus neglectus.

Ključne besede: mikroorganizmi, jamska mikrobiologija, kras, Slovenija.

\section{CAVE MICROBIOLOGY}

Cave microbiology has recently been established as a new interdisciplinary field of microbiology, geology and chemistry dealing with microscopic life that resides in caves and influences natural cave processes. In the last decades the recognition of microorganisms in geological processes in caves altered our perception of cave ecosystems (Barton \& Jurado 2007). In Slovenia as well as elsewhere in the world cave microbiology is still in its infancy. Slovenian Classical Karst is of great interest for researchers of different professional backgrounds as it is well karstified and relatively well studied. Estimates obtained from Črnotiče Quarry (Slovenia) showed that void spaces - cavernosity - in Slovenian karst represents $3.9 \%$ (Knez et al. 2004), which means that this is a potential habitat which can be colonized by the adapted cave (micro)organisms. A potential to find specialized higher organisms in such environments is very high (Pipan \& Culver 2007), it can also be expected that a huge variety of different groups of cave-adapted microorganisms will be found.

${ }^{1}$ Karst Research Institute SRC SASA, Titov trg 2, SI-6230 Postojna, Slovenia; e-mail: janez.mulec@guest.arnes.si

Received/Prejeto: 07.12.2007 


\section{TRACES OF MICROBIAL PRESENCE}

Barton (2006) defined several features within caves which can be identified as evidence of microbial activity: dots on surfaces, unusual coloration of speleothems, precipitates, corrosion residues, structural changes and biofilms. In Slovenian caves microbial communities and their interactions have been studied in various microenvironments. One of the pioneering studies on microbial mat covering cave walls was conducted by Megušar and Sket (1977) in the cave Planinska jama. Another interesting interaction of microbes with the rock surface is formation of so called "cave silver". The term is frequently used by cavers due to its weak silver fluorescence when illuminated by a light source. These water droplets are formed near the cave entrance where cold and warm air are mixed and their presence is probably connected with condensation (Mulec et al. 2002). In caves many times "cave gold" is also observed by visitors (Fig. 1). The golden aspect of colonies usually appears when illuminated and water droplets frequently magnify the yellowish pigment of the microbial mat beneath the water film. These mats are observed in places covered with sediments or other energy sources brought by floods or percolation water; in short at places where organic matter enters the caves. Besides heterotrophs one has to keep in mind also the presence of photoautotrophic organisms in caves. In the illuminated parts of the cave, cave entrances and places deep in show caves illuminated by artificial light (Fig. 1), greenish mat is composed predominantly of cyanobacteria and green microalgae (Mulec et al. in press).

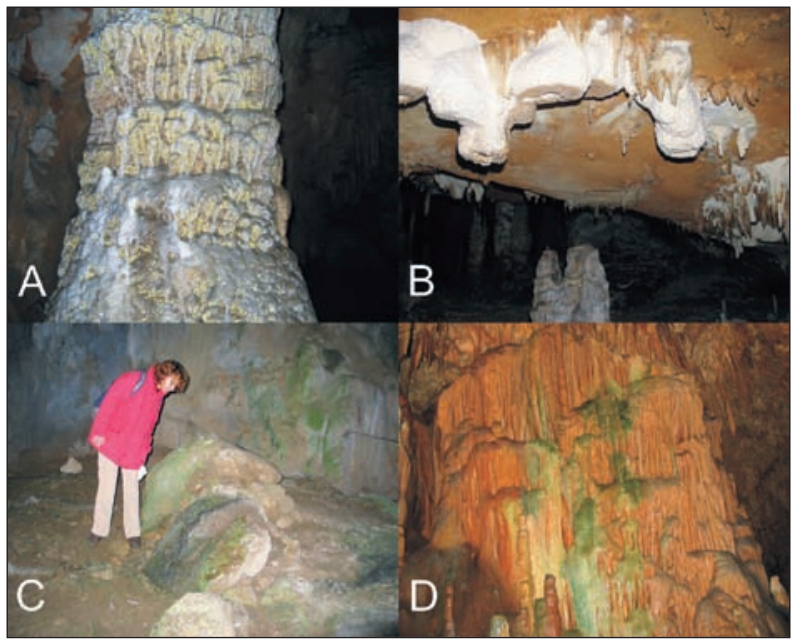

Fig. 1: Examples of microbial colonization in caves. (A) Microbial mat known as cave gold, (B) stalactites of calcite moonmilk, (C) stromatolitic stalagmites, (D) lampenflora.

Many microbes which enter caves are not adapted to cave conditions and their colonies on various substrata are of short duration, but their biomass can notably influence usually nutrient-deficient cave environment. This can be the case also in caves with high allochtonous organic input due to human activity where decomposition processes start to take place. Microbial presence is very well observed in guano, animal excrements, and dead animals.

\section{BIODETERIORATION AND BIOSPELEOGENESIS}

Microorganisms in caves are involved in lithogenic processes, e.g. speleothem deposition and cavern enlargement (Engel et al. 2004, Cañaveras et al. 2006, Mulec et al. 2007) and litholitic processes. The latter, which are completely undesirable from the human perspective, were extensively studied in caves with prehistoric paintings and their role in degradation discussed (Asencio \& Aboal 2001, Cañaveras et al. 2001, Schabereiter-Gurtner et al. 2002).

Many times microbial presence can be observed indirectly. Sometimes inside caves large surfaces of weathered limestone can be noticed, which is a result of incomplete dissolution by carbonic acid in the cave environment under specific conditions, and remain on the passage walls (Zupan Hajna 2003). Corrosion residues can be result of microbial metabolic activity and are fur- ther involved in dissolving of the host rock. In samples of weathered limestone from the caves Pečina v Borštu and in Martinska jama Mulec et al. (2002) retrieved $1.1 \times 10^{6}$ colony-forming units per gram $(\mathrm{CFU} / \mathrm{g})$ and $1.3 \times 10^{3}$ $\mathrm{CFU} / \mathrm{g}$ of wet mass, respectively.

An interesting example of carbonate precipitation in the form of calcite rafts is a pond periodically filled with water in Pečina v Borštu cave where Mulec et al. (2002) obtained $2.5 \times 10^{4} \mathrm{CFU} / \mathrm{ml}$. In the same study Mulec et al. (2002) sampled moonmilk in the cave Snežna jama na Raduhi in the Alpine region of Slovenia where they calculated $6.4 \times 10^{2} \mathrm{CFU} / \mathrm{g}$ (Fig. 1). Moonmilk is defined as the result of disintegration of bedrock and speleothems or as mixed deposition of calcite crystals and water (Hill \& Forti 1997). In the study of calcite moonmilk from Altamira cave, Cañaveras et al. (2006) concluded that mi- 
crobes actively change the physicochemical precipitation of moonmilk, resulting in formation of variety of fibre crystal morphologies, sizes and fibre networks. Another example is stromatolitic stalagmites (Fig. 1) and stalactites, the growth of which is enhanced by carbonate deposition promoted by cyanoprokaryotes towards sun- light (Taboroši 2006). In Slovenia these structures were studied in Škocjanske jame (Mulec et al. 2007). It seems that such biogenic carbonate formations can be far more widespread in subaerial habitats if microalgal propagules meet adequate ecological factors for growth.

\section{TRANSPORT OF MICROBES}

As elsewhere in the environment viable microbial propagules and other tiny droplets float in the air in caves due to their low specific gravities and are disseminated by air currents. Classical method for measurement of airborne microorganisms relies on culturing when an agar medium is exposed to the environment. Bioaerosol microbes on agar plates are collected primarily due to gravity (Buttner et al. 1997). Using this procedure in a simple experiment performed in December of 2001 in the cave Pečina v Borštu (total length of the cave is 240 meters) close to the entrance 68 CFU was observed on an agar plate and at two sampling points close to the end of the cave 106 and 113 CFU, respectively. Petri plates with nutrient agar were exposed for 20 minutes to the cave atmosphere, transferred to the laboratory and cultivated at
RT for 7 days. Due to the winter air inflow in caves the highest CFU being at the end of the cave is not surprising. Microbes are passively transported by airflows which depend on the seasonal air circulation and thus represent an important mode of spreading of inoculum in different parts of caves. Another carrier of microbes in caves represents dripping and seeping water. With heterotrophic plate count which gives us estimates on live heterotrophic bacteria in water Gerič et al. (2004) found from a single trickle in Škocjanske jame that each day $2.2 \times 10^{4}$ bacteria as CFU are released in the cave from areas above the cave ceiling. Besides air currents and water flow, introduction of microbes by animals and humans is an important mode of transport deep in the karst underground (Dobat 1970).

\section{ENERGY INPUT}

Caves and other subterranean habitats have long been recognized as a nutrient-deficient environment. Energy sources and nutrients can enter caves as atmospheric gases, as soil-derived aromatic and polyaromatic compounds, percolating via surface water, and reduced metal ions such as $\mathrm{Mn}^{2+}$ and $\mathrm{Fe}^{2+}$ within the rock itself. Some cave condensates contain various small aromatic compounds that microbes can use as carbon and energy sources (Barton \& Jurado 2007). Some underground ecosystems are totally self sufficient. Movile cave in Romania is the most known example with rich and diverse subterranean fauna with a chemolithoautotrophy-based ecosystem and bacteria as primary producers (Sarbu et al. 1996, Kinkle \& Kane 2000). Among others caves in the world another such example was recently discovered Ayallon cave in Israel (Por 2007).

Caves are usually devoid of sunlight: that is why primary production based on photosynthesis cannot develop. This is not the case in cave entrances illuminated by sunlight and in show caves around lamps where a complex phototrophic community named lampenflora develops (Dobat 1972, 1998, Martinčič et al. 1981). Interestingly, in caves some cyanobacteria and microalgae in this community can survive even at photon flux densities lower than their photosynthetic compensation point (Mulec et al., in press).

A completely different situation on energy sources are caves with high energy input either via a polluted underground stream and by polluted epikarst water from the unsaturated zone (Pipan 2005). Bacteria which enter caves by percolation water can be considered a considerable food source for metazoans (Gerič et al. 2004). Sudden floods bring high amounts of allochtonous organic matter and organisms and consequently heterotrophic decomposition processes can begin. Sometimes even when the source of pollution is removed the previous condition is not restored.

The great majority of microbial species do not inhabit such energetically favourable conditions. They have to survive under extremes of near-starvation or oligotrophic conditions, defined as having less than $2 \mathrm{mg}$ of total organic carbon (TOC) per litre. Nutrient resources 
in caves rarely reach as high as $0.5 \mathrm{mg}$ of TOC per litre (Barton \& Jurado 2007). What is interesting is the fact that in such oligotrophic condition up to $10^{6}$ cells of different bacterial species per gram of rock material is easy to find (Barton \& Jurado 2007). This is in accordance with findings from some Slovenian caves where relatively high bacterial biomass was retrieved by cultivation method (Mulec et al. 2002, Gerič et al. 2004). To overcome limitation, selfish competition for resources is replaced by cooperative and mutualistic microbial associations (Barton \& Jurado 2007).

\section{CAVE MICROORGANISMS}

In caves different habitats are populated by different microorganisms: bacteria, fungi, algae and protozoa. Microbes are usually identified in water bodies, rocky surfaces, on sediments and in guano. Another important group of microorganisms are those which developed different type of interaction with troglobiotic animals, e.g. epibionts and parasites on cave animals (Golemansky \& Bonnet 1994).

\section{BACTERIA}

As discussed above various microbial mats can be traced in caves. Megušar and Sket (1977) identified species composition of organic covers from the walls in the cave Planinska jama. Beneath an etched rocky surface was observed. The majority of bacteria belonged to Gram positive cocci, rods and pleomorphic shaped cells. Several bacterial isolates were retrieved in laboratory conditions: Bacillus subtilis, Bacillus cereus, Bacterium brevi, Proactinomyces polychromogenes. Based on the morphology and biochemical tests Mulec et al. (2002) identified different bacterial groups in silver flashing droplets known as cave silver, in a pond with calcite rafts and in weathered limestone. In the all studied microenvironments fluorescent pseudomonads seemed to be prevalent bacteria which can be due to their versatile metabolic pathways. In caves various types of mats are largely made up of actinomycetes (Groth et al. 1999). In permanent drips with high biodiversity of meiofauna in Škocjanske jame Gerič et al. (2004) established that bacterial communities contained low proportions of Gram-positive bacteria with high incidence of Enterobacteriaceae and Vibrionaceae and practically no culturable actinomycetes.

\section{CYANOBACTERIA AND MICROALGAE}

In caves cyanobacteria and algae can be found in water bodies (Kuehn et al. 1992, Sanchez et al. 2002) and in aerophytic subaerial habitats (Golubić 1967, Dobat 1970). Aerophytic cyanobacteria and algae are easily observed in the cave entrance illuminated by direct or indirect sunlight and, in show caves equipped with artificial illumination, as a part of a lampenflora community around lamps. Dobat (1972) named spots with growing lampenflora "ecosystems in formation". In Slovenian subaerial environments 197 cyanobacterial and algal taxa have been identified up to date by different authors: Črna jama (Martinčič et al. 1981), Huda luknja (Krivograd Klemenčič 2007), Kostanjeviška jama (Mulec 2005), Krška jama (Krivograd-Klemenčič \& Vrhovšek 2005), a lead and zinc mine in Mežica (Mulec 2005), a mercury mine in Idrija (Mulec 2005), Pekel pri Zalogu cave (Martinčič et al. 1981, Mulec 2005), Pilanca cave (Martinčič 1978), Pivka jama (Martinčič et al. 1981, Mulec 2005), Postojnska jama (Dobat 1973, Martinčič et al. 1981, Mulec 2005), Račiške ponikve cave (Mulec 2005), Škocjanske jame (Golubić 1967, Martinčič et al. 1981, Mulec 2005), and Županova (Taborska) jama (Martinčič et al. 1981, Mulec 2005). In the last comprehensive study on cave phototrophs Mulec (2005) found out that Aphanocapsa muscicola, Chlorella sp., Lyngbya sp., Synechocystis sp. and Trentepohlia aurea are very common taxa in cave habitats. In the same study on poorly illuminated walls in Škocjanske jame a typical cave cyanobacteria Geitleria calcarea was reported for the first time in Slovenia (Mulec 2005). From the cave entrance in Škocjanske jame in the phototrophic community of stromatolitic stalagmites, 35 taxa were identified with a low portion of coccoid cyanobacteria and taxa such as Calothrix sp., Homoeothrix sp. and Schizothrix sp. In carbonate depositions on the illuminated side of stalactites in the same cave entrance 14, mainly coccoid, cyanobacteria were identified (Mulec et al. 2007).

\section{FUNGI}

An important group of organisms found in caves are fungi colonizing different substrates, including excrement of higher animals that occasionally enter or live inside caves. Fungi usually form complex microbial consortium with other microorganisms. For example, among diverse bacterial biota in microbial mat covering rocky surface Megušar and Sket (1977) identified Penicillium sp. and Aspergillus sp. and in weathered limestone Mulec et al. (2002) isolated fungus belonging to Cladosporium herbarum group. 
Using their adaptability and versatile metabolic pathways, fungi develop various types of interactions with other organisms. During the investigation of the mycoflora associated with cave-inhabiting fauna from Kozlov rob several hyphomycetes and zygomycetes were identified on living larvae, adults and dead bodies of cave crickets Troglophilus neglectus (Zalar et al. 1997, GundeCimerman et al. 1998). In association with the cave cricket a new species of Mucor troglophilus was described which was regularly found on living T. neglectus adults and on larvae (Zalar et al. 1997). From dead bodies of T. neglectus 30 fungal species were isolated representing 21 different genera, 18 species and 12 genera from the dead larvae and 15 genera and 19 species from the body of adult animals. Fungi isolated with the highest frequency from the larval stage belonged to the genus Mucor. The dominant fungus isolated from the adult stage was an entomopathogen Beauveria bassiana. Besides other facultative pathogens such as Aspergillus, Cladosporium, Penicillium, Mortierella and Geotrichum several ubiquitous soil saprophytic fungi were isolated as well (GundeCimerman et al. 1998).

Troglophilic moths Scoliopteryx libatrix and Triphosa dubitata are frequently infected with entomopathogenic fungi (Kubátová \& Dvořák 2005). Life and dead imagos of troglophilic moths S. libatrix and T. dubitata from 14 Slovenian caves (Apolonova jama, Bečka jama, Dimnice, Huda luknja, Jama pri Pruhu, Jama Školjka, Koblarska jama, Kološevka, Mačkovca, Petrova jama, Pilanca, Špehovka, Turkova jama, Zelške jame) were screened for the presence of entomopathogenic fungi. Beauveria bassiana, compared with the incidence of Paecilomyves farinosus and Lecanicillum fusisporum, appeared with the highest frequency (Tkavc 2007).

The neotenic cave amphibian Proteus anguinus is the only obligate cave-dwelling vertebrate in Europe and the most characteristic animal of underground waters in Dinaric karst. More than 250 localities of $P$. anguinus are known (Sket 1997). At some specimens kept under laboratory conditions at the Department of Biology in the Biotechnical faculty, University of Ljubljana, sudden development of disease symptoms and death of animals after few days was recorded. The causative agent were fungi from the genus Saprolegnia which hyphae penetrated deep into skin tissue and in this way most probably destroyed the osmotic equilibrium in $P$. anguinus. Fungi from the genus Saprolegnia are ubiquitous in freshwater bodies (Kogej 1999).

\section{PROTOZOA}

Amoebae and other protozoans are an integral part of all ecosystems. Their dynamics and community structure is an important indicator of biotic and abiotic changes in the environment. In Slovenian caves up to now no comprehensive study has been performed on this topic. Mulec and Walochnik (2007) isolated from a cave pool with calcite rafts in Pečina v Borštu cave the potentially pathogenic Acanthamoeba castellanii genotype T4 and Hartmannella vermiformis. Both amoebae can serve as vectors for intracellular pathogenic bacteria. From weathered limestone from the same cave vahlkampfiids were identified (Mulec \& Walochnik 2007).

\section{BIOTECHNOLOGICAL ASPECT OF CAVE MICROORGANISMS}

Biotechnological and bioremediation potential of cave inhabiting microorganisms is still not exploited enough. Many microbes have the potential to harbour different important substances which can be effective under low (cave) temperature and thus interesting for industry such as antibiotics and tumour suppression substances. For example in Carlsbad Cavern novel species of microorganisms that can degrade complex hazardous aromatic compounds, such as benzothiazola and benezenesulfonic, were isolated. Microbes can use these compounds involved in the manufacture of plastics as an energy source for their growth (Barton 2006). Microor- ganisms isolated from cave-dwelling fauna are also a significant source of biotechnological important substances. For example some fungal isolates from the cave cricket Troglophilus neglectus obtained in previous studies (Zalar et al. 1997, Gunde-Cimerman et al. 1998) showed high chitinolytic, lipolytic and proteolytic activities (Glavan 1997). 


\section{FUTURE PERSPECTIVES}

Slovenian karst caves offer a great potential in many aspects for cave microbiology. It is worth to continue locating and identifying microorganisms which inhabit different niches in caves, e.g. various bio-mediated crusts on sediments, calcite rafts, cave pearls, ... Studies should go beyond the taxonomy in a direction of understanding the role of microbes in geochemical processes. The evidence for extant microbial processes in caves became more compelling with the discovery of other mineral deposits what were difficult to explain through purely geologic or inorganic processes, such as pool fingers. These structures were proved to be microbial in origin. Today we know that many carbonate minerals within caves are associated with the heterotrophic bacteria, including metastable carbonates, such as valerite (Barton \& Jurado 2007).

To study cave microbiology it is of crucial importance to preserve caves in their intact state; that is why introduction of alien microbiota in caves must be reduced to minimum. Cave microbiology offers immense potential to study evolution relationships and use of alternative sources of energy developed by microbes for scavenging of scarce nutrients in oligotrophic environments. It can also give answers of limits of life and help us to identify the geochemical signatures of life.

\section{ACKNOWLEDGEMENT}

Some results included in this paper were accomplished in the framework of the project no. Z6-7072 "Role and significance of microorganisms in karst processes" supported by the Slovenian Research Agency.

\section{REFERENCES}

Asencio, A.D. \& M. Aboal, 2001: Biodeterioration of wall paintings in caves of Murcia (SE Spain) by epilithic and chasmoendolithis microalgae.- Archiv für Hydrobiologie: Supplementband 140, Algological studies 103, 131-142, Stuttgart.

Barton, H.A., 2006: Introduction to cave microbiology: a review for the non-specialists.- Journal of cave and karst studies, 68, 2, 43-64, Huntsville.

Barton, H.A. \& V. Jurad o, 2007: What's up down there? Microbial diversity in caves.- Microbe (Washington, D.C.), 2, 3, 132-138, Washington.

Buttner, M.P., K. Willeke \& S.A. Grinshpun, 1997: Sampling and analysis of airborne microorganisms.- In: Hurst, C.J., G.R. Knudsen, M.J. McInerney, L.D. Stetzenbach \& M.V. Walter (eds.), Manual of environmental microbiology. American society for microbiology, 629-640, Washington.

Cañaveras, J.C., S. Cuezva, S. Sanchez-Moral, J. Lario, L. Laiz, J.M. Gonzales \&, C. Saiz-Jimenez, 2006: On the origin of fiber calcite crystals in moonmilk deposits.- Naturwissenschaften, 93, 27-32, Heidelberg.

Cañaveras, J.C., S. Sanchez-Moral, V. Soler, \& C. Saiz-Jimenez, 2001: Microorganisms and microbially induced fabrics in cave walls.- Geomicrobiology journal, 18, 3, 223-240, New York.
Dobat, K., 1970: Considérations sur la végétation cryptogamique des grottes du Jura Souabe (sud-ouest de l'Allemagne).- Annales de spéléologie, 25, 4, 872907, Paris.

Dobat, K., 1972: Ein Ökosystem in Aufbau: Die "Lampenflora Schauhöhlen".- Umschau in Wissenschaft und Technik, 72, 15, 493-494, Frankfurt.

Dobat, K., 1973: Ein Beitrag zur eingangs-, Lampen- und Pilzflora der Postojnska jama (»Adelsberger Grotte« bei Postojna, Jugoslawien).- Razprave, Slovenska akademija znanosti in umetnosti, 16, 2, 123-143, Ljubljana.

Dobat, K., 1998: Flore de la lumiére artificiélle (lampenflora-maladie verte).- In: Juberthie, C., \& V. Decu (eds.), Encyclopaedia biospeleologica, Tome 2, Société de Biospéologie, 1325-1335, Moulis-Bucarest.

Engel, A.S., L.A. Stern \& and P.C.Bennett, 2004: Microbial contributions to cave formation: New insights into sulfuric acid speleogenesis.- Geology, 32, 369372, Boulder.

Gerič, B., T. Pipan \& J. Mulec, 2004: Diversity of culturable bacteria and meiofauna in the epikarst of Škocjanske jame Caves (Slovenia).- Acta carsologica, 33, 1, 301-309, Ljubljana. 
Glavan, G., 1997: Production of enzymes by Mucor fungi, isolated from cave cricket Troglophilus neglectus.Graduation thesis, University of Ljubljana, Biotechnical Faculty, p. 64, Ljubljana.

Golemansky, V. \& L. Bonnet, 1994: Protozoa.- In: Juberthie, C. \& V. Decu (eds.), Encyclopaedia Biospeleologica, Vol. 1, Société de Biospéologie, 23-33 Moulis, Bucarest.

Golubić, S., 1967: Algenvegetation der Felsen: Eine ökologische Algenstudie im dinarischen Karstgebiet.- In: Elster, H.J. \& W. Ohle (eds.), Die Binnengewässer, Band XXIII, E. Schweizerbart'sche Verlagsbuchhandlung, p. 183, Stuttgart.

Groth, I., R. Vettermann, B. Schuetze, P. Schumann \& C. Saiz-Jimenez, 1999: Actinomycetes in karstic caves of northern Spain (Altamira and Tito Bustillo).Journal of microbiological methods, 36, 115-122, Amsterdam.

Gunde-Cimerman, N., P. Zalar \& S. Jeram, 1998: Mycoflora of cave cricket Troglophillus neglectus cadavers.- Mycopathologia (1975), 141, 111-114, Den Haag.

Hill, C. \& P. Forti, 1997: Cave Minerals of the World.2nd edition. National speleological society, p. 463, Huntsville.

Kinkle, B.K. \& T.C. Kane, 2000: Chemolithoautotrophic micro-organisms and their potential role in subsurface environments.- In: Wilkens, H., D.C. Culver \& W. Humphreys (eds.), Ecosystems of the World 30, Subterranean ecosystems, Elsevier, 309-318, Amsterdam.

Knez, M., T. Slabe \& S. Šebela, 2004: Karstification of the aquifer discovered during the construction of the expressway between Klanec and Črni Kal, Classical Karst.- Acta carsologica, 33, 1, 205-217, Ljubljana.

Kogej, T., 1999: Infection of Proteus anguinus with the fungi of the genus Saprolegnia.- Graduation thesis, University of Ljubljana, Biotechnical Faculty, p. 97, Ljubljana.

Krivograd Klemenčič, A, 2007: Algae in selected aquatic and terrestrial habitats - floristic and ecological view.- Dissertation thesis, University of Ljubljana, Biotechnical Faculty, p. 210, Ljubljana.

Krivograd-Klemenčič, A. \& D. Vrhovšek, 2005: Algal flora of Krška jama cave, Slovenia.- Sborník národního muzea v Praze, Řada B, Př́rodní vědy, Historia naturalis, 61, 1-2, 77-80, Praha.

Kubátová, A. \& L. Dvořák, 2005: Entomopathogenic fungi associated with insect hibernating in underground shelters.- Czech mycology, 57, 3-4, 221-237, Praha.
Kuehn, K.A., R.M. Oneil \& R.D. Koehn, 1992: Viable photosynthetic microalgal isolates from aphotic environments of the Edwards aquifer (central Texas).Stygologia, 7, 3, 129-142, Leiden.

Martinčič, A., 1978: Primarna produkcija v jamskih sistemih, 1. faza.- Raziskovalna skupnost Slovenije, p. 53, Ljubljana.

Martinčič, A., D. Vrhovšek \& F. Batič, 1981: Flora v jamah z umetno osvetlitvijo.- Biološki Vestnik, 29, 2, 27-56, Ljubljana.

Megušar, F. \& B. Sket, 1977: On the nature of some organic covers on the cave-walls.- Proceedings of the $6^{\text {th }}$ international congress of Speleology, Academia, 159-161, Olomouc.

Mulec, J., 2005: Algae in the karst caves of Slovenia.- Dissertation thesis, University of Ljubljana, Biotechnical Faculty, p. 149, Ljubljana.

Mulec, J., G. Kosi \& D. Vrhovšek, 2007: Algae promote growth of stalagmites and stalactites in karst caves (Škocjanske jame, Slovenia).- Carbonates and evaporates, 22, 1, 6-9, Troy.

Mulec, J., G. Kosi \& D. Vrhovšek, in press: Characterization of cave aerophytic algal communities and effects of irradiance levels on production of pigments.Journal of cave and karst studies, Huntsville.

Mulec, J., P. Zalar, N. Zupan Hajna \& M. Rupnik, 2002: Screening for culturable microorganisms from cave environments (Slovenia).- Acta carsologica, 31, 2, 177-187, Ljubljana.

Mulec, J. \& J. Walochnik, 2007: Amoebae in carbonate precipitating microenvironments in karst caves.Geophysical Research Abstracts, v. 9, European Geosciences Union, Wien.

Pipan, T., 2005: Epikarst - a promising habitat: copepod fauna, its diversity and ecology: a case study from Slovenia (Europe).- ZRC Publishing, p. 101, Ljubljana.

Pipan, T. \& C. Culver, 2007: Regional species richness in an obligate subterranean dwelling fauna - epikarst copepods.- Journal of biogeography, 34, 854-861, Oxford.

Por, F.D., 2007: Ophel: a groundwater biome based on chemoautotrophic resources. The global significance of the Ayyalon cave finds, Israel-. Hydrobiologia, 592, 1-10, Den Haag.

Sanchez, M., J. Alcocer, E. Escobar \& A. Lugo, 2002: Phytoplankton of cenotes and anchialine caves along a distance gradient from the northeastern coast of Quintana Roo, Yucatan Peninsula.- Hydrobiologia, 467, 1-3, 79-89, Den Haag.

Sarbu, S.M., T.C. Kane \& B.K. Kinkle, 1996: A chemoautotrophically based cave ecosystem.- Science, 272, 5270, 1953-1955, New York. 
Schabereiter-Gurtner, C., C. Saiz-Jimenez, G. Pinar, W. Lubitz \& S. Rolleke, 2002: Cave paleolithic paintings harbour complex and partly unknown microbial communities.- FEMS microbiology letters, 211, 711, New York.

Sket, B., 1997: Distribution of Proteus (Amphibia: Urodela: Proteidae) and its possible explanation.- Journal of biogeography, 24, 263-280, Oxford.

Taboroši, D., 2006: Biologically influenced carbonate speleothems.- In: Harmon, R.S \& C. Wicks (eds.), Special Paper 404: Perspectives on Karst Geomorphology, Hydrology, and Geochemistry - A Tribute Volume to Derek C. Ford and William B. White, Geological Society of America, 307-317, Boulder.
Tkavc, R., 2007: Identification and genotypization of entomopathogenic fungi isolated from troglophile moths Scoliopteryx libatrix L. and Triphosa dubitata L..- Graduation thesis, University of Ljubljana, Biotechnical Faculty, p. 80, Ljubljana.

Zalar, P., G.L. Hennebert, N. Gunde-Cimerman \& A. Cimerman, 1997: Mucor troglophilus, a new species from cave crickets.- Mycotaxon, 65, 507-516, Ithaca.

Zupan Hajna, N., 2003: Incomplete solution: weathering of cave walls and the production, transport and deposition of carbonate fines.- ZRC Publishing, p. 167, Ljubljana. 